\title{
(2) \\ Primroses versus Spruces: Cultural differences between flora depicted in British and Polish children's books
}

\author{
Łukasz Łuczaj
}

\section{Education}

\begin{abstract}
Plant illustrations encountered by children during their education directly result from the actual native culture and flora and simultaneously shape children's perception of vegetation. Children's book illustrations were compared in Great Britain, a country with a long tradition of realism in visual arts, and Poland (89 books were studied in each country). It was found that British children's books contained more species of plants and less species of fungi, but the differences were not significant. The proportion of native woodland species is the same for both countries, but Polish illustrations show less woodland flowers and more trees. British illustrations contain proportionally more purple and yellow flowers. Polish illustrations do not reflect the potential natural vegetation (deciduous forests) but rather reflect species typical for disturbed sites and boreal elements of the flora, which are dominant in the countries east of Poland. This can be explained by population movements which took place after 1945.
\end{abstract}

\section{Abstrakt \\ llustracje roślin, z którymi stykają się dzieci podc- zas swojej edukacji, są produktem kultury kraju $i$ jego flory, jednocześnie oddziałują na ich percepcję roślinności. $\mathbf{W}$ pracy porównano ilustracje $\mathbf{w}$ bajkach dziecięcych Wielkiej Brytanii i Polski (po 89 książek). Celem pracy było sprawdzenie czy, $z$ powodu silnych tradycji realistycznego rysownictwa, bajki brytyjskie pokazują więcej gatunków roślin. Stwierdzono, że ba- jki brytyjskie mają więcej gatunków roślin i mniej ga- tunków grzybów niż polskie, jednak różnice nie były istotne. Udział gatunków rodzimych w ilustracjach jest zbliżony, jednak brytyjskie ilustracje mają więcej roślin zielnych, a polskie gatunków drzewiastych. Bry- tyjskie ilustracje mają więcej kwiatów fioletowych i żółtych, a polskie więcej kwiatów białych. Wydaje się, że polskie ilustracje $w$ mniejszym stopniu pokazują}

dominującą potencjalną roślinność naturalną (lasy liściaste), a w większym elementy borealne pospolite w lasach wtórnych i na wschód od Polski. To odchylenie może być wytłumaczone przyczynami historycznymi (zmiana granic po roku 1945).

\section{Introduction}

When I first set foot in Britain about twenty years ago I was amazed by the amount of real plants, realistically drawn wild species native to Britain, shown on mugs, cups, toys and in books. In my home country, Poland, plants seemed to be drawn without care for detail. Flower motifs, for example, were drawn in a completely abstract style, with colours and shapes invented by the artist.

Drawing and painting plants has long been an important part of British education and culture, particularly in Victorian and Edwardian times, when women in the countryside would be experts not only in growing but also in drawing plants, the most beautiful example being the diary of Edith Holden (1977). Realistic plant illustrations became particularly popular due to the Art Nouveau move-

\section{Correspondence}

Łukasz Łuczaj, Academy of Humanities and Economics in Łódź, Department of Humanities, International Institute of Education through Art, ul. Rewolucji 1905 r. nr 64, 90-222 Łódź, POLAND.

lukasz.luczaj@interia.pl

Ethnobotany Research \& Applications 7:115-121 (2009)

Published: April 14, 2009 
ment, which was initiated in Britain by the Arts and Crafts movement and is characterised by organic, especially floral, and other plant-inspired motifs, as well as highly-stylised, flowing curvilinear forms (Duncan 1994). The fruits of these times are such classic illustrated children's books as the works of Beatrix Potter, published between 1901 and 1930, and the Flower Fairies series by Cicely Mary Barker, published between 1923 and 1948. However the tradition of realistic representation of flowers in British art was already strong earlier, e.g. in the mid-19th century, among Pre-Raphaelites (des Cars 2000, Mancoff 2003). Some children's books published in the second half of the $20^{\text {th }}$ century are also masterpieces of botanical illustration. Here we should mention the series of books by Molly Brett, e.g., Good Night Time Tales (1982) or Flip Flop's Secret (1962), and Blyton's Treasury of Verse (1979).

In contrast to Britain, where the legacy of Victorian and Edwardian decorative arts is omnipresent, the Polish version of Art Nouveau - Młoda Polska - left few realistic plant decorations except for exquisite realistic stainedglass windows depicting wild flowers in the Franciscan Church in Cracow (Zbijewska 1986). In Poland there was also very little interest in the history of plant motifs in art with the exception of the book by Szafer and Szaferowa (1958), in contrast to the wide interest in the art of botanical illustration in Britain (Blunt 1967). Although a few children's books containing rich botanical illustrations were published in Poland, e.g., the Razem ze Słonkiem series written by Maria Kownacka (1975) and illustrated by Zbigniew Rychlicki and Jerzy Heintze, as well as books by Włodzimierz Scisłowski $(1986,1987)$, they never achieved such a place in national culture as Potter's and Barker's books in Britain.

Art is often a good source of information about culture. Obviously plant illustrations reflect local habitats, but there is usually some cultural filter which causes only certain plants to be shown. The plants chosen are often those which are more useful (e.g., maize in South America, dates in Egypt) or those which are regarded as most beautiful (e.g., lotus, bamboo, plum and peach blossom, and peony - in China) or plants associated with religion (e.g., the grapevine in Christianity). These emphasised plants become known by the community, commonly recognised, and easy for children to learn. On the other hand, plants which are not depicted are less visible, analogous to the way in which things which have no names usually have no significant value in the culture. An analogy to Sapir-Whorf theory (Ferraro 2004) could work here: the plants which were not illustrated are no longer noticed by the younger generation, who in turn are even less likely to illustrate these plants themselves. This creates a spiral effect in which plants initially recognised as most important strengthen their cultural position. The relationships between the existence of exact names of biological taxa and the cultural position of these taxa was discussed extensively by Berlin (1992).
The decreasing degree of contact that children have with nature and their decreasing taxonomic expertise and ecoliteracy are becoming an important issue in education. The innate interest that humans have in other living beings (sometimes called biophilia), is particularly strong amongst children and is important for their cognitive development (Kellert 2002, Wilson 1984). It has been observed in Poland that a few decades ago children had considerable knowledge of wild edible plants, which they exercised and transmitted while tending cattle in pastures. Such knowledge and its use are largely extinct now due to the fact that children are no longer used as shepherds (Łuczaj 2008). This kind of decrease in popular botanical knowledge seems to be a global trend (e.g., Atran et al. 2004, Bebbington 2005, Cooper 2008, Wolff et al. 1999). In this present day reality a large proportion of the contact which children have with nature is vicarious (based on watching television, reading books etc). The taxonomic exactness of representations of plants in children's books is therefore an important issue, since they are becoming a major source of information about the environment.

This study was designed to compare two, quite distinct, European cultures (British and Polish) in relation to the above mentioned issues. I initially hypothesised that British culture is more oriented towards realistic depiction of nature, whereas Polish culture emphasises only a few culturally important plants. The following hypotheses were put forward:

1. British children's illustrations contain more species of plants per book.

2. British children's illustrations are more adequate in showing local flora.

3. British children's illustrations show less mushrooms than the Polish ones, as Poles are a strongly mycophilous nation, who utilise many species of mushrooms in nutrition (Marczyk 2003).

The comparison between the flora of the children's book illustrations in Britain and Poland is particularly interesting because the actual floras of Britain and Poland are not very different. Both the vascular flora of Britain and of Poland have around three thousand wild species including established aliens (Mirek et al. 2002, Stace 1991). A large proportion of the species is the same, as both countries lie nearly at the same latitude and have similar mean annual precipitation and temperature. The two floras, according to my calculations, share 69 percent of species and 95 percent of genera. Apart from the differences caused by much milder winters and generally a more oceanic climate in Britain, most differences in children's illustrations can, therefore, be attributed to cultural factors.

\section{Methods}

An equal number of 89 books for younger (primary school) children, containing at least one drawing of a real species 


\section{Łuczaj - Primroses versus Spruces: Cultural differences between flora depicted in British and Polish children's books}

of plant or fungus, was compared. The study started in England. In winter 2007/2008 I searched two public libraries in Somerset (Porlock and Minehead), as well as three charity shops in Minehead and Bridgwater and three bookshops in Minehead and Bridgwater. Five private home libraries were also catalogued. A total of 89 books containing realistic plant/fungi illustrations were found among over a thousand volumes of literature for children. In summer 2008 I recorded the first 89 books containing such illustrations, which I encountered in Poland: all the books in a public library in Krosno (a small town in SE Poland, similar in size to Bridgwater), five home libraries, one secondhand bookshop and three ordinary bookshops. Overall the number of checked books also exceeds a thousand. The general structure of the set of books from Britain and Poland was similar, and contained books of varying sizes, thickness and amount of pictures: from classic masterpieces of literature to trivial booklets containing one species. Altogether, books by 52 known authors (plus 5 books by unknown authors), illustrated by 54 authors (plus three anonymously illustrated books) were used for the British part of the data set. The Polish books were written by 54 authors (plus five books by unknown authors), and illustrated by 62 authors (plus six books illustrated by unspecified authors). In both datasets the books from the 1970s, 1980s, 1990s and 2000s were well represented (Table 1). However the oldest Polish book was from the 1960s, whereas in Britain the widely available reprints of early20th century books by Potter and Barker were included. Only books illustrated in Britain and Poland were taken into account. This was not an issue in Britain where the vast majority of children books are British and only one non-British (Swedish) illustrated story was encountered during the search. On the other hand Polish libraries and bookshops contain a larger number of translated titles. Up until the 1980s these were mainly Russian books, but in the last few years many French and German illustrated stories for children have been published. The British impact is much less visible, only one translation, of Beatrix Potter stories, was encountered during the search.

Table 1. Date of publication of the analyzed books.

\begin{tabular}{|l|c|c|}
\hline Date of publication & Britain & Poland \\
\hline pre-1960s & 24 & 0 \\
\hline $1960 s$ & 3 & 1 \\
\hline $1970 s$ & 9 & 6 \\
\hline $1980 s$ & 15 & 49 \\
\hline $1990 s$ & 17 & 11 \\
\hline $2000 s$ & 13 & 16 \\
\hline no date given & 8 & 6 \\
\hline
\end{tabular}

A database was created, in which only plants and mushrooms which could be identified to a species or generic level were included, plus, in a few cases, plants which could be identified as two similar genera (e.g. bindweeds:
Convolvulus and Calystegia, or thistles: Carduus and Cirsium). In the genus Rosa, dog-rose (Rosa canina L. and other species from the section Caninae) were distinguished from garden varieties.

The Chi-square test was used to test the significance of differences between the frequency of occurrence of particular commoner species in the two floras, and the MannWhitney $U$ Test was used to test the significance of the difference between the samples from both countries. The Spearman rank correlation coefficient was used to test the correlation between the date of publication and the number of plant species.

Plant names follow Flora Europaea (Tutin et al. 19641980).

\section{Results}

Overall 258 plant taxa and 20 fungi taxa were recorded. However only 145 taxa of plant and 8 taxa of mushroom occurred more than once. The flora of British illustrations contained 216 plant taxa and 14 fungi taxa, and the Polish flora 113 and 14 taxa respectively.

British illustrations were richer in plant taxa (Table 2), but the difference was not significant statistically (Mann Whitney $U$ Test, $P>0.05)$. The modal number of taxa was four in British illustrations, compared to three in Polish illustrations. The difference in mean numbers of taxa showed a similar trend (7.7 for Britain versus 4.6 for Poland). On the other hand the mean number of fungi taxa was higher in Polish illustrations (0.55 taxa per book) compared to British (0.28 taxa per book), but the difference was not significant either.

For Polish books there was no significant correlation between the number of plant taxa and the date of publication (Spearman rank correlation, $r=-0.14, P=0.20$ ), whereas there was a clear negative correlation for British illustrations, even when species-rich early 20th century books were excluded and only post-1970 books were taken into account $(r=-0.51, P=0.0001)$.

British illustrations have relatively less white flowers than Polish illustrations, but more yellow and purple/blue flowers (Table 2). The category of purple and blue flowers is the largest in British illustrations, and that of white flowers in Polish illustrations. In both sets of data yellow flowers are an intermediate category.

British and Polish illustrations had on average an identical percentage of native woodland taxa (both woody and herbaceous treated jointly), but Polish illustrations had a significantly higher percentage of woody (tree and shrub) taxa compared to British illustrations (Table 2). 
Table 2. Comparison of British and Polish children's books plant illustrations. Significance: ns (not significant), ${ }^{*}(0.01<P<0.05),{ }^{* *}(P<0.01)$.

\begin{tabular}{|c|c|c|c|}
\hline & Britain & Poland & \multirow{5}{*}{$\begin{array}{l}\text { Significance } \\
\text { of difference } \\
\text { between } \\
\text { samples } \\
\text { (Mann-Whit- } \\
\text { ney U Test) }\end{array}$} \\
\hline Number of books analysed & 89 & 89 & \\
\hline Total number of plant taxa & 216 & 113 & \\
\hline Total number of fungi taxa & 14 & 14 & \\
\hline Modal number of plant taxa & 4 & 3 & \\
\hline \multicolumn{4}{|l|}{ Mean number or percent per book } \\
\hline Plant taxa & 7.7 & 4.6 & ns \\
\hline Fungi taxa & 0.28 & 0.55 & ns \\
\hline $\begin{array}{l}\text { White flowering herbaceous } \\
\text { plants }\end{array}$ & $11.0 \%$ & $16.1 \%$ & ns \\
\hline $\begin{array}{l}\text { Yellow flowering herbaceous } \\
\text { plants }\end{array}$ & $15.2 \%$ & $9.0 \%$ & ** \\
\hline $\begin{array}{l}\text { Purple and blue flowering } \\
\text { herbaceous plants }\end{array}$ & $15.3 \%$ & $5.6 \%$ & ** \\
\hline Native woodland plant taxa & $37.0 \%$ & $37.0 \%$ & ns \\
\hline Tree and shrub taxa & $28.8 \%$ & $41.2 \%$ & * \\
\hline
\end{tabular}

primrose, foxglove and bluebell are some of the commonest and most "beautiful" native woodland flowers. Other species specific to British illustrations are woodland or forest edge plants (e.g., wild rose, ivy, blackberry), or grassland and garden species such as apple, daffodil and daisy. One may say that British children's book illustrations glorify the understorey flora of woods and hedges. However it must be borne in mind that a certain shift can be observed, as in the most recent children's books (after the year 2000) woodland and hedgerow species give way to garden flowers (e.g., tulips), those wild species commonly grown in gardens (daffodil, foxglove and primrose) and water plants, particularly bulrush, which is easy to draw and recognise.

Some differences in the illustrated flora can be easily explained by differences in vegetation: foxgloves, primroses and daffodils are ubiquitous both in urban gardens and in the

The fifteen most commonly depicted taxa in British illustrations were: blackberry, ivy, oak, primrose, foxglove, field poppy, daisy, daffodil, bluebell, apple-tree, dog-rose, bulrush, fly agaric, garden rose and bindweeds (Convolvulus and Calystegia spp.). For the Polish illustrations these were respectively: bulrush, oak, birch, fly agaric, spruce, garden rose, horse chestnut, "porcini"/"cep" (Boletus sp.), willow, field poppy, dandelion, sunflower, hazel, tulip and wild strawberry (Table 3).

Some species occur commonly in both British and Polish books illustrations, these are oaks, bulrush, fly agaric, garden varieties of roses, field poppies, dandelions and water lilies.

A few species occur exclusively or nearly exclusively in British books. These are primroses, foxgloves, harebells, wild rose, ivy, daffodil, apple-tree and blackberry. In contrast taxa such as: spruce, "porcini" (Boletus sp.), birch, willow and sunflower are restricted mainly to Polish book illustrations.

\section{Discussion}

The species which commonly occur in illustrations (in both countries) usually have two characteristics: they are common, at least in some part of the country, and have a characteristic appearance easily depicted in a simplified form (oak - shape of leaves, birch - white bark, daffodil yellow trumpet-shaped flowers, fly agaric - white-spotted red cap, bulrush - club-shaped inflorescences, etc.).

British illustrations seem to emphasise the most striking flowers found in the British countryside. Such species as countryside, and they are native to Britain. These species are less abundant in Polish gardens and not seen in the wild. On the other hand some species are extremely common in both countries, e.g., apple-tree, dog-rose and bindweed, but are seen primarily in British illustrations, which has to be attributed to cultural differences.

Among the seven species typical for Polish illustrations and rarer in British illustrations (Table 3 ) there are as many as four species of trees (spruce, birch, willow and horse chestnut). It is worth pointing out that spruce is native only in the south and east of Poland, birch and willow are species characteristic of disturbed sites and horse chestnut is an exotic tree. No woodland flowers specific to Polish illustrations can be found, but the most highly valued edible woodland fungus - Boletus - is commonly found. The only woodland flowers relatively common in Polish illustrations are wild strawberry and lily-of-the-valley. The former species grows on forest edges, banks and in woodland clearings, and the latter grows mainly in lowlands, in pine and oak woods. No species can be found which is characteristic of deciduous woodlands, and commonly flowers in Polish woods in spring (e.g., wood anemone Anemone nemorosa L., which is very abundant and striking in woods throughout Poland).

The set of wild plants and mushrooms shown in Polish illustrations are species which range very far in the east towards Belarus and Russia and constitute the main species of the boreal forests of Eastern Europe and Scandinavia (birch, spruce, pine, fly agaric, wild strawberry, Boletus). Birch, spruce and pine in Poland grow in less fertile sites, often on sandy soils or in secondary forests. Except for oak, other native tree species, which are characteristic of the native ancient forest which dominated the vegetation 


\section{Kuczaj - Primroses versus Spruces: Cultural differences between flora depicted in British and Polish children's books}

Table 3. Comparison of the frequency of occurrence of the commonest plants and fungi in 89 Polish and 89 British children's illustrations. Plants were ordered starting from those commoner in British illustrations and finishing with those commoner in Polish illustrations. Significance of difference between Britain and Poland: ${ }^{*}=P<0.05,{ }^{* *}=P<0.001$, ns = not significant (Chi-square Test). Relative abundance in Britain and Poland: +++ (very abundant, seen in landscape in large quantities in the whole country), ++ (very abundant locally or frequent throughout), + (rare or occasional), c (mainly cultivated).

\begin{tabular}{|c|c|c|c|c|c|c|}
\hline \multirow[t]{2}{*}{ Latin name } & \multirow[t]{2}{*}{ English name } & \multicolumn{2}{|c|}{$\begin{array}{l}\text { Number of } \\
\text { Occurances in } \\
\text { Illustrations }\end{array}$} & \multirow[t]{2}{*}{ Significance } & \multicolumn{2}{|c|}{$\begin{array}{l}\text { Relative } \\
\text { Abundance }\end{array}$} \\
\hline & & Britain & Poland & & Britain & Poland \\
\hline Primula vulgaris Huds. & primrose & 17 & 0 & ** & +++ & $+c$ \\
\hline $\begin{array}{l}\text { Hyacinthoides non-scripta (L.) Chouard } \\
\text { \& Hyacinthoides hispanica (Mill.) Rothm. }\end{array}$ & bluebell & 15 & 0 & * & +++ & - \\
\hline Campanula rotundifolia L. & harebell & 10 & 0 & * & ++ & + \\
\hline Digitalis purpurea L. & foxglove & 16 & 1 & ** & +++ & $++\mathrm{C}$ \\
\hline Rosa canina L. & dog-rose & 12 & 1 & * & +++ & +++ \\
\hline Hedera helix L. & ivy & 21 & 2 & * & +++ & + \\
\hline Narcissus pseudonarcissus L. & daffodil & 15 & 2 & * & +++ & $++\mathrm{C}$ \\
\hline Malus domestica Borkh. & apple & 14 & 3 & * & $+++\mathrm{C}$ & $+++\mathrm{C}$ \\
\hline Rubus subgenus Rubus & bramble & 22 & 5 & * & +++ & ++ \\
\hline Convolvulus sp. and Calystegia sp. & bindweed & 10 & 3 & ns & ++ & ++ \\
\hline Bellis perennis L. & daisy & 15 & 6 & * & ++ & ++ \\
\hline Pyrus communis $\mathrm{L}$. & pear & 7 & 3 & ns & $+++\mathrm{C}$ & +++ \\
\hline Trifolium pratense L. & red clover & 7 & 4 & ns & ++ & ++ \\
\hline Iris spp. & iris & 6 & 4 & ns & ++ & ++ \\
\hline Papaver rhoeas L. & field poppy & 15 & 11 & ns & ++ & ++ \\
\hline $\begin{array}{l}\text { Quercus robur L. \& } \\
\text { Quercus petraea (Matt.) Liebl. }\end{array}$ & oak & 19 & 23 & ns & +++ & +++ \\
\hline Taraxacum sp. & dandelion & 9 & 11 & ns & +++ & +++ \\
\hline Corylus avellana $\mathrm{L}$. & hazel & 7 & 9 & ns & ++ & ++ \\
\hline Tulipa sp. & tulip & 7 & 9 & ns & $++\mathrm{C}$ & $++\mathrm{C}$ \\
\hline Nymphaea alba L. & white water-lily & 5 & 7 & ns & + & + \\
\hline Rosa spp. (garden forms) & garden rose & 10 & 17 & ns & $+++\mathrm{C}$ & $+++\mathrm{C}$ \\
\hline Amanita muscaria (L.) Lam. & fly agaric & 11 & 19 & ns & ++ & ++ \\
\hline Pinus sylvestris L. & pine & 4 & 7 & ns & $++\mathrm{C}$ & +++ \\
\hline Fragaria vesca L. & wild strawberry & 5 & 9 & ns & ++ & +++ \\
\hline Convallaria majalis L. & lily-of-the-valley & 4 & 8 & ns & $++\mathrm{C}$ & ++ \\
\hline Typha spp. & bulrush & 11 & 25 & * & ++ & ++ \\
\hline Aesculus hippocastanum L. & horse chestnut & 5 & 15 & * & $++\mathrm{C}$ & $++\mathrm{C}$ \\
\hline Helianthus annuus L. & sunflower & 3 & 11 & * & $++\mathrm{C}$ & $++\mathrm{C}$ \\
\hline Salix spp. & willow & 3 & 12 & * & ++ & +++ \\
\hline Betula spp. & birch & 5 & 21 & * & ++ & +++ \\
\hline Boletus spp. & cep & 2 & 14 & * & ++ & ++ \\
\hline Picea abies (L.) H. Karst. & spruce & 1 & 19 & ** & $++\mathrm{C}$ & ++ \\
\hline
\end{tabular}


centuries ago, are rare. The dominant type of forest in Polish lowlands used to be grąd forests, dominated by oaks, hornbeam and lime-tree (Szafer 1966). However the last two species, as well as maple species, which are also common in the landscape, are rare in illustrations. The dominant type of vegetation in the lower elevations of the Polish Carpathians are mixed beech, fir (Abies alba Mill.) and spruce forests. However, both beech and fir are completely absent from children's illustrations, although they are the dominant trees in the landscape of the Carpathians. The only common mountain plants present in children's book illustrations are spruce, and, to a lesser extent, crocuses, both species typical of higher elevations, particularly in the Tatra mountains and surrounding mountain ranges. Such common, Carpathian woodland flowers as oxslip (Primula elatior Hill) and asarabacca (Asarum europaeum L.) are missing from children's illustrations. We can conclude that the flora of children's illustrations is completely dominated by lowland species, particularly those which are common in northern, north-eastern Poland and further East - in Belarus, Lithuania and Russia. It actually may not be surprising as the Polish borders shifted some $200 \mathrm{~km}$ westwards after World War II. Poland lost a third of its territory, the part dominated by a Belarussian, Ukrainian and Lithuanian population, which first became a part of the Soviet Union (after its invasion of Poland in 1939) and then became part of independent states. Most of the Polish inhabitants of these areas were moved to the areas reclaimed from Germany and joined to Poland. However Polish history and culture is strongly connected with its "lost" eastern regions. The first line of the most popular Polish poetic work of the 19th century, Pan Tadeusz by Adam Mickiewicz says: "Litwo, Ojczyzno moja!" ("Oh, Lithuania, my fatherland!"). Most Romantic poets of the 19th century were born east of the present borders of Poland. Another group of poets, representing the period of Młoda Polska at the turn of the 19th and 20th century, discovered and glorified the Tatra mountains and their presence can be seen as parallel to spruces and crocuses occurring in illustrations. Unfortunately no art movement or known artists have depicted deciduous forest vegetation, which can be admired in national parks, e.g., in the Białowieża Forest. This trend is reflected in children's illustrations and may have a strong influence on children's idea of nature. The plants shown in the illustrations have little connection with real life.

The trend of decreasing realism in plant illustrations in British books is also worrying. Even if it is counterbalanced by the wide availability of photographic identification guides, it indicates a decrease in the connection children and illustrators have with the countryside, the end-product of a process dubbed the "devolution" of ethnobotanical knowledge (Atran et al. 2004, Wolff et al. 1999). This low level of botanical knowledge amongst children has been documented both in Britain (Bebbington 2005) and the USA. (Cooper 2008).

\section{Literature Cited}

Atran, S., D. Medin \& N. Ross. 2004. Evolution and devolution of knowledge: A tale of two biologies. Journal of the Royal Anthropological Institute 10(2):395-420.

Bebbington, A. 2005. The ability of A-level students to name plants. Journal of Biological Education 39(2):6367.

Berlin, B. 1992. Ethnobiological Classification: Principles of categorisation of plants and animals in traditional societies. Princeton University Press, Princeton.

Blunt, W. 1967. The Art of Botanical Illustration. Collins, London.

des Cars, L. 2000. The pre-Raphaelites: Romance and realism. Harry N. Abrams, New York.

Brett, M. 1982. Good Night Time Tales. The Medici Society, London.

Brett, M. 1962. Flip Flop's Secret. The Medici Society, London.

Blyton, E. 1979. Enid Blyton's Treasury of Verse. Purnell Books, Maidenhead, Berkshire.

Cooper C.L. 2008. Botanical Knowledge of a Group of South Carolina Elementary School Students. Ethnobotany Research \& Applications 6:121-127.

Duncan, A. 1994. Art Nouveau. Thames and Hudson, New York.

Ferraro, G. 2004. Cultural Anthropology: An applied perspective. Fifth Edition. Wadsworth/Thomson Learning, Belmont, California.

Holden, E.B. 1977. The Country Diary of an Edwardian Lady. Michael Joseph Ltd., London.

Kellert, S.R. 2002. Experiencing nature: Affective, cognitive and evaluative development in children. Pp. 117-151 in Children and Nature: Psychological, sociocultural and evolutionary investigations. Edited by P.H. Kahn \& S.R. Kellert. MIT Press, Cambridge, Massachusetts.

Kownacka, M. 1975. Razem ze słonkiem. Volumes 1-6. Młodzieżowa Agencja Wydawnicza, Warszawa.

Łuczaj, Ł. 2008. Archival data on wild food plants used in Poland in 1948. Journal of Ethnobiology and Ethnomedicine 4 


\section{Łuczaj - Primroses versus Spruces: Cultural differences between flora depicted in British and Polish children's books}

Mancoff, D.N. 2003. Flora Symbolica: Flowers in preRaphaelite art. Preste, Munich.

Marczyk, M. 2003. Grzyby w kulturze ludowej Polski. Atla 2, Wrocław.

Mirek, Z., H. Pięknoś-Mirkowa, A. Zając \& M. Zając. 2002. Editors of Flowering Plants and Pteridophytes of Poland. A checklist. Krytyczna Lista Roślin Kwiatowych i Paprotników Polski. Instytut Botaniki Polskiej Akademii Nauk, Kraków.

Scisłowski, W. 1986. Wesołe Grzybobranie. KAW, Rzeszów.

Scisłowski, W. 1987. Zielone igraszki: Fraszki dla dzieci o tematyce przyrodniczej. Glob, Szczecin.

Stace, C. 1991. New Flora of the British Isles. Cambridge University Press, Cambridge.
Szafer, W. 1966. Editor of The Vegetation of Poland. Pergamon, Oxford.

Szafer, W. \& J. Szaferowa. 1958. Kwiaty w naturze $i$ sztuce. PWN, Warszawa.

Tutin, T.G., V.H. Heywood, D.M. Burges, D.H. Moore, S.M.Valentine, S.M.Walters \& D.A. Webb, 1964-1980. Flora Europaea. Volumes 1-5. The University Press, Cambridge.

Wilson, E.O. 1984. Biophilia. Harvard University Press, Cambridge, Massachusetts.

Wolff, P., D.L. Medin \& C. Pankratz. 1999 Evolution and devolution of folk biological knowledge. Cognition 73:177204.

Zbijewska, K. 1986. Krakowskim szlakiem Stanisława Wyspiańskiego. Wydawnictwo PTTK "Kraj”, Warszawa Kraków. 
